\title{
HOPE AND GOD AS GOOD-ENOUGH MOTHER: THE DEVELOPMENT OF HOPE IN JOB
}

\author{
ESTHER E. ACOLATSE
}

DUKE UNIVERSITY

\begin{abstract}
Introduction
French Philosopher, Gabriel Marcel, asserts a truth that most have intuited, namely:

Hope consists in asserting that there is at the heart of being, beyond all data, beyond all inventions and all calculations, a mysterious principle which is in connivance with me, which cannot but will that which I will, if what I will deserves to be willed and is, in fact, willed by the whole of my being. (1949, p. 16)
\end{abstract}

And it is almost as if it is by design that the first unattested book of the Bible is believed to be the Book of Job, which could almost be called the Book of Hope, as though to say all begins and ends here, all that life means and can be stands or breaks here. In this essay I will explore, the development of hope in Job(primordial human) through his trials as identified with the developmental strides of an infant who (in Eriksonian and Object Relations Theory terms) navigates the tensions of trust vs. mistrust and finds hope rather than despair due to an environment created by God whom I posit as "good-enough mother." The dynamics at play in the dyadic relationship between the infant and the good-enough mother is noted as corresponding to Job's relationship with God. God ${ }^{1}$ is thus conceived as the primordial good-enough mother, whose mothering produces hope, seen as the primal virtue for human existence. The dynamics and necessity of hope are considered and implications for pastoral theology care and counseling are suggested.

\section{The Contours of Hope}

The Book of Job, with its depiction of a heroic man and his relationship with God, is perhaps the most fascinating book in the Bible. It is also a much studied book, with scholars 
focusing on the issue of the historicity, theodicy, and so on. However, my interest lies elsewhere. I am concerned here with the psychological and theological issues the book raises with regard to hope, and with the formation of the self in relation to the "primary other." Viewing Job's conceptions of God, and the hope that is engendered through the relationship, with Object Relations Theory in hand, psychologically interesting parallels can be drawn between Job's view of God and an infant's conception of the mother or primary caregiver. In fact, the dynamics at play in the dyadic relationship between the infant and the "good-enough mother" is one that corresponds to Job's relationship with God. At the end of Job's story, we observe the epitome of hope, which is the litmus of test, if you will, of good-enough mothering.

Hope is the foundation of existence and the lynchpin for survival and grounding of the human being's life as a person. It is the quietude of surrender and relaxation in absolute trust in the benevolence of an omnipotent other, when all around is hopeless and despair would be the normal course of action. Hope is an indispensable aspect of human existence and well being. It is foundational to humans as meaning making beings, and as Bidwell and Batiski $(2009,1)$ note "is a constitutive element of the abundant life central to Christianity". For that reason pastoral theologians and pastoral care providers who are engaged in helping people find meaning are "agents of hope" (Capps 1995). Yet so often hope can be framed largely as keeping a bright outlook on life despite the moments of despair and even through a Christian existential lens, such hope is conceived as a response rather than a primal existential affect. If hope is the primal existential affect, which psychologically speaking grows out of the infant mother dyad then it stands to reason that its ground and anchor be found ultimately in the primordial parent infant 
mother dyad. Christianly speaking this would be the God human dyad which I find exemplified in the Joban narrative, where the two primary characters, Yahweh and Job constitute the dyadic infant mother matrix. The interchanges between the two characters and the dynamics of the unfolding relationship which issues in enduring hope and trust for Job, despite the seeming indifference of Yahweh to address the immediate demand to alleviate Job's suffering or supply a reason for it, has implications for pastoral theology and care.

Hoping is distinguishable from mere wishing in one significant way, that is, its object has no specificity as such, but it is rather "global, [a] more or less existential condition rather than a thing" (Pruyser, 1990, 2005, p. 533). Always the object of hope is larger than a thing one can wish for; it is a person making or breaking (if one lacks it) response to existence. It is the very ground of being and more. Psychosocial developmental theories assert that the primary developmental ego task for the infant is to negotiate the dynamics of trust/mistrust and have trust "the earliest positive psychosocial attitude" (Erikson, 1964, p. 115) overcome mistrust so that hope is born. And this hope is fashioned from the dynamic interplay of the infant and the primary care provider who need not be perfect, but good-enough to sufficiently affirm the need for omnipotence of the infant, but also frustrate the infant enough to dislodge the illusion of omnipotence.

From a theological and scriptural perspective, hope is seen as one of the three enduring virtues (1 Cor 13:13), borne on either side by faith and love, two virtues it sustains and which in tandem provide comfort to withstand the vicissitudes of life and help undercut despair and apathy. But more importantly is the future direction of hope that spans this life and the next, the glorious eschatological dimension that looks forward towards God's good future. The importance and 
indispensability of hope is further underscored by its foregrounding in the story of Job. While patience in suffering and sometimes faith are often the celebrated messages of Job, hope far outweighs them. This is because from a theological-anthropological perspective, the key verse in this text is "Though He slay me, yet will I trust Him" (Job 13:15, NKJV). Both theologically and psychologically trust, which issues in hope, especially in the absence of all conditions prerequisite for hoping, is born in intimate relationships, of which the parent-child one is the paradigmatic. Images of parent-child relationships pervade the scriptures, whether in the Old Testament in reference to God and Israel or in the New Testament in reference to God, Christ, and the Church. Thus trust, resulting in hope, and the inner dynamics between the two, have both theological and psychological undertones.

One of the most useful psychological theories that allows us to explore the dynamics of the infant primary parent relationship is the psychosocial Object Relations Theory (ORT). ORT has pervaded the psychoanalytic literature in recent decades. Unlike the earlier drive model, in which relations are primarily shaped by the need for drive gratification, relational models primarily focus on relationships in themselves. As the self develops it internalizes its earliest object relations and hence the dyadic relation in the early years of the infant is of special significance. God, I will argue, is a good-enough mother as described in ORT because the classic characteristics that make for good-enough mothering are present in God's relationship with Job throughout this biblical narrative. We see God's doting presence at what may be termed the "beginning" of Job's life, when all was well with him and he was lavished with God's abundance; God's seeming absence through the rough and tumble of his life, the dark days; and finally the evidence of God's enduring presence all 
along and unshakable trust issuing in hope, engendered in Job by the end of the narrative, and these all have parallels in the nurture and results of good-enough mothering according to ORT. However, before we delve into ORT and the explication of its use for a psychological exploration of hope in Job, I offer a recap of the story highlighting portions of relevance to the paper, especially Job's situation and his developing relationship with God.

\section{The Story of Job in Brief}

The NRSV introduces the Book of Job as being an ancient folktale about a patient man which circulated orally among oriental sages and found its present form in the Hebrew bible around 1000-800 B.C., with portions dating as early as the sixth century B.C. It is the story of an upright man who is deprived of both material and familial wealth within a short span of time with no apparent reason that he knows of. In spite of these catastrophes he maintains his faith and trust in God. Although he is subject to the worst possible torture and we see him holding tenaciously to his innocence and demanding justice from God in the presence of three wise dialogue partners. While he waits for justice to be meted out he demands an audience from God, whom he conceives of variously throughout the narrative as at once both gracious and trusted keeper and fierce foe. God finally makes an appearance in good time, but he offers no direct responses to Job's various queries, only a declaration of omnipotence, although God cares enough about Job to reveal himself to him. What is of greater interest in this story is the behind-the-scenes characters and movements especially the part played by God. It is God who makes the observation about Job's character in a manner germane to a parent glorying in a properly sired and brought up child. More importantly, never once was God's eye or control remote from every instance of Satan's (the next important 
character) dealings with Job. A threshold, monitored no doubt by God, was firmly set for all Job had to endure. It is thus the intentionality of the process by which Job's life is orchestrated, the way in which the Almighty sits within the seeming messiness of Job's life, and the way in which the twocreator/creature - are intertwined and affected by each other, that provides impetus for addressing God as good-enough mother as described in ORT. ${ }^{2}$

\section{Object Relations Theory (ORT): An Overview}

Generally ORT sees the development of the self as occurring in three phases, but for the purposes of this discussion only the first two will be employed. The first phase is the infantmother/primary caregiver dyad/symbiosis. Usually this period lasts from birth to about six to eight months, and during this time the infant begins to differentiate between self and mother and there is a move from complete symbiosis to an awareness of the other as separate from self. Initially, self and other are so fused that all experience is felt to be coming either from that one self/dyad or from outside of it. Further, the self experiences things as either all good or all bad and hence develops good and bad self-object units that at first are held together.

Over time, however, as the self begins to differentiate between self and other, it also learns to differentiate between good and bad objects as well as good self and bad self. This is the period of the emergence of reality-testing that involves the mechanisms of splitting, projection, and

introjection. Within a conducive atmosphere - that is, one with a supportive, affirming caregiverthe good self-object image is strongly established and the self begins to form a belief in the goodness of the world (although we must not lose sight of the fact that this belief in the goodness of the world is formed in spite of the presence of bad object as well as bad self). This concept finds 
support in Erik Erikson's psychosocial stages of development, which consists of bipolar crises and their resolution at each developmental stage. Erikson terms the first stage of development the "trust vs. mistrust" stage, with trust as the attitude that births hope, the primary and elemental virtue of the truly alive human being. The human being cannot live without hope, even when the whole world crashes in and trust is shaken; when hope endures, life can go on. Hope is seen as "the enduring belief in the attainability of fervent wishes in spite of the dark urges and rages which mark the beginning of existence" (1964, p. 118). The infant also internalizes the holding environment engendered by "good-enough mothering" - the soothing, comforting atmosphere—and in turn appropriates this for itself, especially during the absence of the mother. Therefore, a favorable ratio of trust over mistrust comes from good-enough mothering.

The second phase is the separation and individuation stage. D. W. Winnicott of the British Object Relations School, who has made enormous contributions to this field, sees this as the stage of relative dependence: "the earliest stage before the child has become sure that anything can exist that is not part of the child" (1971, p. 15). During this phase, the infant begins to fuse the good and the bad object images and the good and bad self to form a realistic self-image in relation to the other. Earlier appropriations of the internalized functions of the good-enough mother are now intensified, and beyond soothing and comforting itself, the child also begins to express affects such as anger and love. An important aspect of this stage is the move towards realistic goals and ideals. For Winnicott, however, the process is more than just the growing ability to do this. Much more importance is attached to the "intermediate state between a baby's inability and his growing ability to recognize and accept reality" (p. 3). Within this space we are entering the realm of illusion and the creativity born of that which forms the bases of creative engagement with the environment, 
including art and religion.

Winnicott's work as a pediatrician led him to the discovery and exploration of another aspect of the world of the infant and his or her relationship with the primary other that is important for healthy development of the self — an aspect tied up with the realm of transitional space and transitional object. Infants normally become attached to an object that they use for comfort in times of anxiety, especially during the absence of the mother. The importance of this phenomenon, as Winnicott points out, is not so much the object per se as the use the child makes of it. A paradoxical element is always involved in the child's use of the "transitional object" (p. xii), for the object is both at once given to the child and created by the child. Thus Winnicott cautions that no attempt be made at resolving the paradox.

Along with the nature of the object, the place of the object - outside, inside, at the borderand the infant's capacity to recognize the object as "not-me," the ability to initiate the affectionate object-relationship occurs in the transitional space. This is the space between subjective and objective experience. This intermediate area, which Winnicott describes as one "of experiencing" and to which both inner reality and outer life contribute, is:

an area that is not challenged, because no claim is made on its behalf except in that it shall exist as a resting-place for the individual engaged in the perpetual human task of keeping inner and outer reality separate yet interrelated. (p. 2)

Of primary importance in all this is the mirroring function of the dyadic relationship between mother and child. The infant begins life with scattered and diffuse bits of experience. Organization of these experiences into a unified and meaningful whole depends to a large extent on the mother's organized perception of the child. The mother not only provides a holding environment, the 
relational space in which the child is contained and has experiences, but mirrors back to the child what he or she is while "bring[ing] the world to the child" (p. 3). In reflecting back the child's expression of him- or herself (especially in these early stages of development when the quality of his or her experience is fragmented and formless), the mother aids in the task of the infant's selfintegration. The good-enough mother knows when to meet the child's needs at precisely the time the infant is, as it were, conjuring up the object that will satisfy the need. Though "[t]he infant cannot be said to know at first what is to be created, ... [a]t this point the mother presents herself . . The mother's adaptation to the infant's needs, when good-enough, gives the infant the illusion that there is an external reality that corresponds to the infant's own capacity to create" (p. 12).

But the mother also knows how to provide a non-demanding presence that allows the child to acquire the capacity to be comfortable with being alone. Initially this is a capacity to be alone in the presence of the mother or another, but gradually this leads to a capacity to be alone by oneself. Furthermore, this is the stage at which the child is learning object constancy and thus begins to have an awareness of the existence of the mother when she is absent, goes through the emotions of trust versus mistrust, and learns to wait in hope for the mother's return. The mother, in Eriksonian terms, has now "become an inner certainty as well as an outer predictability" (Erikson, 1964, p. 147).

Altogether the following qualities/characteristics are essential for good self-integration and for engendering hope in the infant: (1) the optimum dyadic relationship between mother and infant; (2) the paradoxical relationship between the child and the transitional object; (3) the use of the transitional object and the adequate stimulation of the infant in order to allow the child space to be by himself and learn needlessness; and (4) the space within which to play, to hallucinate, and to create illusions, the illusory experience, and the phenomena of experiencing. Within these 
parameters, the first psycho-social hurdle the infant negotiates (the pull and push of trust vs. mistrust) yields hope rather than despair; a hope that undergirds the infant's stance throughout life.

There is no doubt that what is being primarily worked out through the dynamic relationship between mother and child is a movement towards the attainment of hope, though the word is hardly ever explicitly used in most of the psychological literature dealing with ORT. But hope is central to the life and particularly to the task of faithful Christian living and care-giving. Paul Pruyser suggests that the reluctance to be explicit about hope is largely because it is "a boundary concept" (1963, p. 86) and thus the domain of many of the disciplines, but that this apparent reluctance is "only a verbal and cognitive phenomenon. After all, as professional healer the psychiatrist is by implication a hopeful, hoping and hope-instilling person who works with hope, believing practically in its efficacy" (p. 86). And so it is with the Christian theologian and especially pastoral counselor; hope is a quintessential characteristic, for the bases of belief for God's good future and the task of helping people become unstuck and propel their lives forward require a hopeful attitude in both caregiver and care-seeker.

\section{(God's)Mothering (of) Job}

What occurs in Winnicott's representation of ORT may thus be said to mirror the story of Job's relationship with God. For beyond the issue of why the righteous suffer, most people would remember the story of Job for its resounding hope. There is something fascinating about Job's relationship with God. Right from the opening scenes of the drama we hear God in his court address Satan: "Have you considered my servant Job, that there is none like him on the earth, a blameless and upright man who fears God and turns away from evil?" (Job 1:9). This is clearly an indication of a relationship between the Job and God that God is pleased by, for he is obviously boasting about 
Job here. One can almost hear a mother's delight in the tone of this question, as if to say, "I know this child of mine and I can trust him not to disappoint me." Such knowledge, however, can only come from a close relationship between the two. The depth and dynamics of the relationship and the close affinity it has to that which object relations theories have observed in the mother/child relationship is made most evident in the dialogues between Job and his friends as well as between him and God in the course of his sufferings.

One outstanding feature is the balance we see of trust to mistrust in Job's attitude to and understanding of God. This is most evident in Job's images of God in Job's opening soliloquy (Ch. 3), the dialogue discourses (Ch. 4-27), and the closing soliloquy (Ch. 29-31).When the first disaster strikes and Job loses all his children in one day, we hear him declare in what Walter Vogels, in tracing the spiritual growth of Job, calls "the language of popular faith" (1981, p. 77)—words one would expect from a pious man:

Naked I came from the womb

naked I shall return

The LORD gives and the LORD takes away

blessed be the name of the Lord. (Job 1:21)

— and that chapter ends with the statement that "[t]hrough all this Job did not sin, did not charge God with unreason." Then the second disaster strikes and even Job's wife urges him to curse God and die (Job 2:9). But again Job's response depicts the trust a child has in his mother. One African proverb says that a child is never scalded by a piece of hot yam a mother puts in its hands. Job's apt response to his wife's urging is that they should be ready to receive from God both good and bad (Job 2:10). 


\section{Trust/Mistrust Dance}

Erikson's first stage of human psychosocial development (1963, pp. 247-251) is played out in these moments of Job's life. As Erikson points out, it is the bipolar crisis of trust/mistrust that the child goes through as, for instance, he waits for the mother's next appearance after her absence, and the cycle of holding these in tensive unity, as well as the child's ability to stay the course or not, that over time generates the virtue of hope or its opposite, despair. Hope is engendered if a good-enough mother is the caretaker who appears at the optimal time for the child's need; and despair is what ensues if mothering is inconsistent at best. In Job's narrative, when we move away from the prologue for a moment, we soon see almost complete trust transformed to an oscillation between trust and mistrust. Job seems to feel one and then the other, and then sometimes both simultaneously (see Job 1:13-22, 2:7-10; 6-7 especially 6:1-11; and then 9-16:7 respectively).

The movement above replays Winnicott's $(1965,1971)$ observation that the growth of the self does not progress in a linear fashion from the subjective omnipotence of the infant towards a more mature appreciation of object reality, but rather that the path to growth is by oscillating between feelings of subjective omnipotence and object reality. Crucial to growth is what occurs within the intermediate, transitional, or play space between infant and mother and the use of the transitional object as well as the transitional phenomena in general. The transitional object is experienced as both given to and created by the infant and occupies the play space - the transitional space — between the infant and the mother and thus acquires a paradoxical quality (inside, outside and at the border) that it is essential not to resolve.

The transitional object here, I suggest, is Job's image of God, both given to Job by God's 
intimate interaction with him (which we adduce from God's own introduction of Job as someone God takes delight in and is proud of [Job 1:6-12, especially 29:1-6]), as well as created by Job in the intermediate space of experiencing, that transitional space between God's intimate presence and seeming absence. Between his oscillating trust and mistrust and their corollaries hope and despair. In the same way that the infant is oblivious to the source of this transitional object and its use within the borderlands of the transitional space, so is Job like the child with his transitional object, unaware of the conflicting composite image of God $(6: 4,8-9)$ and of the paradox embedded in his complaints and lament (7:3-21; and then 16:7-14 and 30:18-23). More to the point, however, is how God, the good-enough mother of Job, refuses to acknowledge or resolve the paradoxical image Job has created of God. God's silence throughout Job's complaints — complaints that we could equate in ORT and in the light of our argument with a child's crying, whining, and even tantrum-throwingall aid in Job's journey towards object reality. God's seeming indifference to Job's cries could be likened to that of a mother who has learnt to discriminate between the infants various distress signals by attunement to the infant and thus attending in a timely fashion in correspondence to a particular sensed need. In fact, when God finally shows up, supposedly at one of Job's summons to plead his case, God further intensifies the paradox. God invites Job to behold God's majesty and omnipotence, when it is precisely on account of God's omnipotence that Job expected God would either come to his defense or would not (Job 38ff). Job wanted and expected (based on his past experience) a God who was either all good and gracious and would rush to his aid at the least need (akin to an infant's understanding of mother-subjective omnipotence) or one who was unjust and wicked who indeed was out to destroy him (what I would call an either/or god); however, God was all the while inviting Job to a clearer vision and perspective of himself, priming Job to an 
understanding of the Almighty as a both good and bad, not an either/or but a both/and God. And he does finally reach that moment of object reality when he owns the distinctions between his god images and the God who confronts and comforts him (Job 40: 3-5; 42: 1-6)

In this interchange one is drawn to just how much room God leaves Job for what Winnicott calls "play." One can envisage the temporal space between Job's requests for audience with God and God's appearance as analogous to the Winnicotian transitional space. This is a play area-a transitional space — within which Job, like a child, learns about reality and the true nature of God, as he plays with his transitional object, which I have earlier suggested as Job's god image. It is within this space that Job enters and weaves his god images, his concepts of God; and one can almost imagine God sitting by watching this child at play in the same way that a mother does. The goodenough mother, who appeared hitherto perhaps almost on demand providing for Job's every comfort, is now permitting Job to differentiate between psychic and external reality as he plays with the various god images. Here he begins to learn that the God of one's fantasy is not God as such. Although what Job goes through may be considered too painful and serious to be labeled "playing," nevertheless "playing" in this sense is an intense activity requiring that one's whole being be involved, and which can have profound effects on an individual, especially when the one at play is a child. The object of play can become anything in the subjective realm of playing (a marble can become a bomb in war games). Winnicott points out several important implications and benefits of playing. Playing spontaneously without inhibition requires trust and a trusting environment. Playing has been known to have therapeutic effects, and the therapist patient relationship has often been portrayed in this light. Again, analogously, God/god-image becomes anything Job needed it to be at the time. Further, Job's laments and several monologues in which he manipulates his god-image, 
demanding audience with the Almighty, display such spontaneity and lack of inhibition precisely because of the trusting relationship between him and God. At the same time, these tirades/laments/long arguments with God, no doubt had therapeutic effects, easing some of the suffering of Job. Additionally, the delay in God's response to Job's demands allows separation between God and Job that provides the ground for independent seeking of God, who is outside the production of Job's fantasies and desires. The loss Job feels at the silence of God is the precursor to his acquiring the mature capacity to be alone, waiting in the silence until God appears on his ${ }^{3}$ and not Job's schedule. It is in this transitional space that Job develops trust and learns hope.

As Job's suffering intensifies, and his images of God change, so does his concept of God grow. This concept, and the language in which it is couched, seems to progress through "the language of popular faith" with its simplistic concept of God as wholly good (by human standards) to a more complex concept of God who seems inscrutable (Fowler, 1971; Dykstra and Parks, 1986). In object relation terms, Job is beginning to fuse the good and bad object images and the good and bad self image to form not only a realistic self-image in relation to the other but also to form a realistic image of the other.

Both psychologically and theologically, hope is born through our attitude to stressful circumstances along with the support of others and the resources of faith. Thus adverse circumstances often come as a test and basis for hope. When one feels hemmed in from all sides, as the word "crisis" implies, then one either despairs or hopes.

Job's sufferings, which lead to a clearer understanding of God, began when God removed the "protective hedge" around Job in the same way that the good-enough mother allows the child to learn "needlessness" by not attending to his or her every whim. The good-enough mother breaks 
the illusion of "all-me" by weaning and other distancing actions, and though this seems quite different from what God is doing in this story, the analogy is clear. I own that what happens in Job's case is an extreme case of neglect, but this is a God/man relationship and we know the end of the story. Moreover we also know that God does put a limit to how far Satan can go with Job.

\section{God-images and Growth of Self}

In Job's first soliloquy, in which he curses the day of his birth and cries out in his agony, he mentions that what he feared most has befallen him. There is a clear correlation between the language Job uses and his concept of God. As pointed out earlier, when his language is that of the popular faith of his time, his image of God is simplistic, but his concept of God gets more complex as his language moves away from the rudimentary language of trust that is akin to resignation. Initially he almost seems to split his image of God in the way that a child does, separating good and bad images. Though he owns that human beings must be prepared to receive both good and evil from the hands of the Lord (Job 1:20, 2:10) he did not "charge God with wrong." Psychologically, as Elisabeth Kubler-Ross (1969) points out in her studies on terminally-ill patients, this could be called the language of denial. However, for Job this denial changes to anger, and a shift in the God image occurs in his soliloquies and discussions with his three friends. He sees God as a hedge that hems him in and blocks his progress (3:23). God is a hunter who has put his arrows into him and has arrayed His terrors against him (6:4). God is one who mocks at the calamity of the innocent (9:23) and finds the innocent perverse (9:20).

Then another shift takes place and Job's language of denial and anger moves into an oscillation between trust and mistrust. God is seen and acknowledged as creator and preserver of 
life who loves him and yet who all the while was plotting evil against him (10:12-13). God is seen as the all-seeing and caring eye, ever fixed on Job, and who marks him every time he commits a sin (10:14). Job obviously holds two opposing views of God in tension here. And as Carl Jung puts it: He cannot deny that he is up against a God who does not care a button for any moral opinion and does not recognize any form of ethics as binding. This is the greatest thing about Job, that, faced with this difficulty he does not doubt the unity of God . . . Yahweh is not split but is an antimony - a totality of inner opposites — and this is the indispensable condition for his tremendous dynamism, his omniscience and omnipotence. (1973, p. 10)

Through his suffering, then, Job's concept of God becomes more holistic, neither purely good nor purely evil (by human understanding) but an enigma, unfathomable by human minds. Thus both extreme dualism and strict monism are overcome through a more realistic relationship which yields a more nuanced understanding with God. This is now a God who though "unsafe" is also absolutely trustworthy and thus inherently good. To see Yahweh as both the source of good and evil is different however form seeing Yahweh as both inherently good and evil. It is in this case not dissimilar to that of the infant who experiences the good-enough mother as both the source of its comfort in terms of nurture and care, as well as discomfort. Of course the analogy breaks down invariably since we are comparing God and human, for while God is always aware and in control of the of situations termed evil or good-enough, the mother is only sometimes partially aware of the actions that constitute evil or adversity in the sense of what actions contribute to "frustrate" the infant towards growth in hope. While in Judeo Christian teaching and belief suffering is viewed as one of the divine pedagogical methods that God uses to teach humans to 
grow, it is always inferred by the sufferers retrospectively. While in the throes of suffering as the Deuteronomistic history of Israel points to, there is always the assumption that they are being punished (which is often the case when they have contravened any of the laws as ritual codes). This raises a fairly knotty point which defies fool-proof answers and leads into the very theodical analysis that is not central to this article, and yet which is unavoidable. Is God then the source of evil and what are we to take away from the numerous texts in the Hebrew Bible that gesture towards God as the source of evil? ${ }^{4}$ But the Hebrew word "ra" - evil, does not always connote moral evil but also adversity which is the sense in which it is being used here. The thesis/antithesis pattern in the phrasing underscores this interpretation.

Mingled with this paradoxical concept of God is Job's trust and confidence that this God initially conceived as proving totally unjust, will justify him. But as Job's concept of God changes, so too does his trust shift, moving from mistrust to trust and from one to the other. At the same time these moments of trust and mistrust correlate to moments of hope and hopelessness. Job swings from one to the other, as a child often does in crises of anxiety, until he begins to trust explicitly and thus to hope against all the odds as his friends' as well as his own arguments mount up. It is, as it were, a hope against hope. And so hope and hopelessness dog one another, and trust and mistrust oscillate in the appropriate holding environment in which God, the good-enough mother, does not rush to the rescue of suffering child. God, one could say, instead prolongs God's own suffering in this waiting period by expanding Job's capacity to play, an act which finally results in engendering hope in Job.

In other words, Job's journey to trust in God is like that of the infant who, through appropriate frustration in the meeting of its needs, comes to experience the good-enough mother as 
distinct from itself; the good-enough mother who is not just all good or all bad, but is simply "goodenough" to be trustworthy and foster hope even when disappointments come.

Job desires to come to God and place his complaint before him because he believes him to be just. At the same time he knows that this is impossible. "But how can a man be just before God?" (9:2). "If I summoned him and he answered me, I would not believe that he was listening to me" (9:16). In spite of his mistrust of the justice of God, Job is certain that God will acquit him if God but hears him out (13:13-22). He cries out in agony and curses the day on which he was born. He also blames his mother throughout this lament (Ch. 3). In his first address to God (Ch. 14), he laments the misery and utter haplessness of man and wishes that he were in Sheol, although he still hopes that God will set a day aside to remember him (14:13). Indeed God has pulled down his hope like a tree (19:10). Yet in the same chapter he pronounces his unshakable trust in God:

For I know that my Redeemer lives and at last he will stand upon the earth and after my skin has thus been destroyed then from my flesh I shall see God whom I shall see on my side and my eyes shall behold, and not another. (19:25-27a)

Here Job's hope and trust, like his concept of God, holds two inner opposites in tension. So complete is his new understanding of God in this regard that he expects to find within God both an advocate to defend him as well as a judge. As Jung points out:

As certain as he is of the evil in Yahweh, he is equally certain of the good. In a human being who renders us evil we cannot expect at the same time to find a helper.

But Yahweh is not a human being; he is both a persecutor and a helper in one, and the one aspect is as real as the other. (p. 7)

This is Job's hope, to be vindicated and acquitted and discharged and to live to see the day. This is 
not mere wishful thinking; the odds against it are too great. It is not a delusion either, for Job's speeches show great clarity of thought. If either wishful thinking or delusion were the possible frame of reference within which Job was operating, he would have sunk beneath the weight of the deluge of the physical and mental suffering he was undergoing, not to mention the apparently sound arguments offered by Eliphaz, Bildad, and Zophar. It is the distinct characteristic of hope that it stands not over and against all argument but beyond all argument.

\section{Hope: The Fruit of Good-enough Mothering}

Job's journey through a range of emotions ultimately points to hope or "hoping." Indeed, "hoping" - the verb in the progressive tense that is Gabriel Marcel's preferred term (p. 16) appropriately underscores the progressive nature or process of hope. Furthermore, such hope defies case studies; it refuses to be part of the statistic of "such cases," it "rises to the plane which transcends the level of all possible empirical disproof - the plane of salvation as opposed to that of success in whatever form" (ibid.,). The crux of hope has eschatological moorings and telos and therefore is not about everyday wishes, even though they are important. The source, direction, and object of hope are such that it must yield fruit.

Clearly by this definition, Job is right at the centre of this phenomenon described as hope, and despite the difficulties he faces from friends, from himself, and even from God, what he seeks ultimately, along with the desire to see God in his flesh, is salvation. Although according to ancient Israelite understanding to see $\mathrm{El}$ is to die, to see God as Redeemer is to live. As we learn from the New Testament epistles "this hope does not disappoint," but it is hope only when in our helplessness and hopelessness we do not depend on ourselves but on the other, and in this instance on God. 
Marcel further suggests that hope can be defined as the will when it is made to bear on what does not depend on itself. Thus will/strong will, as long as its steadfastness is exocentric rather than egocentric, bears the qualities of hope. So hope is not an "inactive state of the soul" nor a "stoical... stiffening of the soul." On the contrary, it is "relaxation and creation" (p. 20). However, it is definitely not a relaxation that is passive, for hope is active. The soul still searches hungrily for meaning but is, as it were, cocooned in calm assurance, in spite of all uncertainties, as it goes about its creative task for the welfare of the person. And indeed Job in his hoping begins to "create" God. That is, Job begins to strip away his false ideas of God, those inculcated in him by the popular faith of his time, by his wife, and even by his theologically savvy and well-meaning friends, to reveal something quite different. When God does appear before him in the final scenes, in spite of the vitriolic content of Job's concept of God earlier, God commends Job's "creation" (Job 42:7-9).

Paul Pruyser (1963), as mentioned above, points out certain characteristics that distinguish hope from other related affects, but, basing his arguments on W. C. M. Scott's stages of hope, he also emphasizes the importance and significance of hope for survival in both humans and animals. According to Scott, when a person's activities are not rewarded with the satisfaction of the basic wishes, he or she first waits for the wish to be gratified, and if this does not occur, then waiting turns to anticipating, to pining, and finally to hoping. The absence of the gratifying object when one is wishing, leads to "hallucinations" while the subject waits for the images to be turned to gratifying sensations. What occurs in anticipating is an expectancy to obtain the sensory gratification. In pining one's waiting and anticipating combine with the desire for change, for sensory gratification and for the object that will satisfy the sensation. But "[i]n hoping, finally there is also a belief that an object is forthcoming which has itself the desire to satisfy the hoper" (p. 89). 
On the surface these internal activities might not appear to be different, but in hoping for what one waits for there is not just a sensory gratification, not just an object to satisfy a need, but the belief that the object itself desires to gratify the need. The relationship between the good-enough mother and the infant is such that the infant is aware of the mother's desire to satiate the infant's impulsive needs in the prompt appearance of the breast, for instance, to the cry of hunger, and the mother's awareness of the infant's need of the breast. This finds confirmation in Marcel's statement about the conniving aspect of hope, and as Pruyser puts it "in other words, hope presupposes a rather emotional relation between persons in whom mutual desires for satisfaction occur" (p. 89). In Job's hope for acquittal he believes that the object of his hope - the Redeemer-will take his part and is in fact already on his side. When God appears in the final scenes, he shows that he was on Job's side. But we will return to the final scenes of this drama later.

Marcel goes on to point out other attributes of hope and he does this by distinguishing hope from wishing or daydreaming. First, while wishing and daydreaming have specific objects—one can always articulate what one is wishing for or daydreaming about — the object of hoping is not as clearly defined. It is vaguer, more diffuse, and broader in scope. Second, in wishing or daydreaming we are detached from the reality of a situation. In daydreams we seek an escape from the moment and try to live in another time frame and on another plane. But this is not so with hoping. The hoping person is in the thick of the situation, always a part of what is going on. And that is why hoping involves patience, because one cannot escape from the present reality of the situation by any flight of fancy.

These ideas clearly apply to Job. Job's hope is for larger things—-salvation, life — and his hope even takes on an eschatological quality. Also, Job does not resort to daydreaming, but learns to 
wait with patience. This patience has the quality of more than waiting, in fact is it waiting with an added air of expectancy. We see this virtue epitomized in his resounding words of hope and their numerous "ands." Even within the initial words of resignation to God's will uttered during the first cycle of disasters, Job was very present in his sufferings. He was so much a part of the scheme and reality of his sufferings that his three friends, Eliphaz, Bildad, and Zophar, were initially speechless in his presence, and his wife's admonition to curse God and die was an offer of escape from the present calamity and its vicissitudes. He had become contemptible in the eyes of all who saw him; he was changed to the point that he no longer knew himself. He had become, as it were, a nonbeing. Now if the trials that Job underwent were to be measured on a current psychological stress scale, they would be more than anyone has been called to bear in a life time. Donald Capps, in his discussion of crisis counseling methods based on the Book of Job, gives the mean stress value of Job's life events based on the Holmes and Rahe stress scale as 544 and adds that "there is no question that Job was a prime candidate for 'cumulative stress overload.'" Job spoke directly from the midst of his sufferings (1990, p. 45).

\section{Hope's Reward}

Both psychologically and theologically, hope has its rewards. I will give attention in these last few pages to the rewards of hope and also dwell on the more theological aspects of hope. Pruyser argues that Christianity has been paramount in emphasizing the primacy of hope in human existence:

Ever since its origins, Christianity as a movement has forced theological and philosophical thinkers to become explicit about hope, to inculcate hope, to assume hope, to extol hope, to help people towards hope. (1963, p. 87) 
And hope certainly plays a significant role in the final scenes of the Book of Job. During the course of his sufferings Job, convinced of his innocence, virtually demands that God appear to him and in a face to face duet, as it were, he will demand answers to numerous questions - questions that deal primarily with God's governance of the universe. For Job to expect the transcendent God to appear to him at his summoning is well nigh preposterous, let alone coming before him in litigation. As Elihu reminds him:

It is not for a mortal to set a time

To come before $\mathrm{El}$ in litigation. (34:23)

While we might conceive that God might take pity on and appear to a Job who confessed to whatever wrong that was the cause of the suffering, it is hard to see God responding to a man who virtually shakes his fist in the face of God and demands a hearing! But then, contrary to popular expectation, God does appear and does speak. The hitherto transcendent becomes immanent. And he does not come to condemn; he comes to affirm and reward. Job's fortunes are restored and he has children in his old age. In fact, his reward goes far beyond his hope.

Although $\operatorname{God}^{5}$ does appear in a whirlwind and in "terror," it was not to terrify Job but to affirm his concept of God. Eliphaz and his two friends, who seemed to sound theologically more correct, were reprimanded for their insincerity:

After the LORD had spoken these words to Job, the LORD said to Eliphaz the Temanite: My wrath is kindled against you and against your two friends; for you have not spoken of me what is right, as my servant Job has. (42:7)

In the light of this affirmation from God, Job's repentance in 41:6 as a repenting of wrongdoing is thus inappropriate. Norman C. Habel, for instance, sees this as Job withdrawing his case against God now that he has spoken to God face to face and has received, as it were, a clearer understanding 
or view of God. Job is therefore repenting of the "dust and ashes" with which he has been clothed and "identified as litigant and humiliated sufferer," (1985, p. 583) since he is about to leave this role.

It is also interesting to note that when God comes to defend himself he engages in a sort of play with Job. God sets up a court scene and invites Job to arraign him. "Gird your loins as a hero" is the imperative, but all in all God takes into account Job's demand for litigation, and one is struck by the structural and thematic similarities between Job's accusations before God and God's defense before Job. As Habel points out, God's speeches offer "repeated allusions, innuendos, and ironic hints at earlier claims and accusations of Job" (p. 530), but through this engagement Job comes to understand not only the order in the universe despite its apparent arbitrariness, but also gains a fuller knowledge of God, whom he has now seen face to face. And in this face to face encounter, no doubt, a mirroring takes place: Job also comes to know himself. He comes to a new understanding of his self-worth and rises up from the dust and ashes of mourning to the new responsibility of a greater fortune (42:10-17).

But who is this God who as it were "comes" and who is it that Job acquires greater or perhaps more nuanced knowledge of? A legitimate question in light of the arguments and analysis of Job's developing self and his trust and hope in God. First, the comparisons and arguments in this paper takes into account that there are continuities and discontinuities between an infant's acquisitions of object constancy as theorized by ORT and what we are arguing for with regarding Job's new image of God. While OTR theorizes development through object constancy and suggests that the transitional object in aid of the process is both given to and created by the child; and even though we are making analogies between what pertains in the infant mother dyad and the of Job and God, there are also points of discontinuity. In the same way that the nature of the 
mother as experienced by the infant is both external and internal "at the border", so it seems it is with Job. In using ORT to explain Job's image (or "creation”) of God, it is implied that Job“s image is different from God who exists outside Job's inner world. Here Ana Maria Rizzuto's concept of the "birth of the living God" (Rizutto, 1979) demonstrates only partially what Job may have arrived at; but there is more. While there is no doubt an intersubjective component at work in Job's concept of God, it does not however negate or replace the God who transcends Job's intersubjective experience and who appears to him. This is a tricky point, for as Christian tradition seeks to point out; the God revealed is at the same time the God concealed. Additionally, who God is in himself (in se) and who God is for us (pro nobis) is not something humans can begin to know nor spend time speculating. For the God we encounter is always Emmanuel. So, when Job finally could build trust God in the whirlwind of suffering experiences, it is also on God the One who exists out there as a separate Being, beyond his intersubjective experience, for it is in this that Job's growth and development is evinced.

\section{Conclusion}

This discussion of the process of engendering hope in Job has several implications for pastoral theology, care and counseling. If, as the literature indicates, hope is the one requisite for survival, and if all those engaged in the healing professions are by virtue of that fact hoping and hope-instilling persons, that is "agents of hope", there is the need for definite but appropriate ways to generate hope in individuals. In short, there continues to be need for more work in the psychology and theology of hoping. While it is beyond the scope of this paper to explore all the ways this can be done, a few observations that might guide future work are in order. First, we learn from Job that hope comes from lament (Swinton, 2007), as well as from asserting oneself before God, an oft 
ignored component of Christian theology and formation, as Pembroke $(2010,43)$ asserts. The emphasis, especially in Reformed theology, on the sovereignty of God has left little room for the kind of childlike boldness witnessed in the account of Job. A timid religiosity on the one hand or a brazen sense of entitlement on the other (often witnessed in the prosperity Gospel popularized by Televangelism) seems to be the way most Christians relate to God. The pastoral theological task of forming people for right worship - "the chief end of man"- needs to attend to cultivating in church members the answer to the question the catechism poses: namely, to know God and to enjoy him forever. While this paper has not been about theological issues of theodicy, it seems to me that the concept of God as good-enough mother (rather than one perfect by human standards) has a great deal to contribute to how we theologize about suffering and evil—and the apparent absence of God-in pastoral practice, particularly in counseling or preaching. A good-enough mother, has the right mixture of fallibility, weakness, and strength to relate in the mutuality of love with weak humanity and to engender in humanity the most fundamental virtue of hope upon which the very essence of life depends.

There are also implications for pastoral theological approaches to care and counseling. Pastoral theologians and care providers are already cognizant of the need for the ministry of presence with care seekers. The concept of God as good-enough mother argued for in this paper calls for moving beyond a ministry of presence into what Friedman (1985) describes as "nonanxious presence". For a ministry of presence can yet be intrusive by making presence felt, a being there "thereness" as it were, which indirectly demands a certain response from the care seeker, an intrusive silence louder than words and action. What I see as the presence- in- absence of God in Job's situation (situation here used in Farley's (2000) sense of events which demand a response 
from us rather than mere occurrence) points to the way in which counselors may be with care seekers.

If hope is the primal existential affect, which psychologically speaking grows out of the infant mother dyad then it stands to reason that its ground and anchor be found ultimately in the primordial parent infant mother dyad. The interchanges between the two characters and the dynamics of the unfolding relationship which issues in enduring hope and trust for Job, despite the seeming indifference of Yahweh to address the immediate demand to alleviate Job's suffering or supply a reason for it, has implications for the therapeutic relationship between the counselor and counselee. It has the potential to reframe how counselors approach care to suffering individual who are asking where God is in the midst of their suffering by helping them conceptualize with the aid of the therapist how a God who is a good-enough mother may use suffering sometimes as a means of stabilizing and developing the ego while not being the direct source or cause of evil. We must be cautious of course about the possibilities and tendencies for this concept to be misused in the same way that abusive parents can make excuses for neglect, whereas the good-enough mother knows when to be present and absent and use both in tandem for fostering a trust and hope. Pastoral theologians and care givers can learn to stay in the moment with the care seeker and not always rush to offer needed relief without themselves becoming good-enough mothers, a holding ground for the development of hope for clients and parishioners as the case may be.

Finally is the overarching theme which has pastoral theological implications with direct bearing on pastoral care and counseling is that not all situations of unease/suffering require situational change for ego strength to be regained by the counselee. Care and counseling thus does 
not always need to work towards redress in all situations within the therapeutic relationship before a good end is seen as the beneficial outcome.

\section{$\underline{\text { Endnotes }}$}

${ }^{1}$ It is important to mention from the onset that on reading Job, one ought to factor in the assumption that we do not encounter a fully developed picture of God in this portion of scripture. What we have is a literary portrayal with which I'm taking appropriate liberties. Thus the notion of God as "good-enough mother" employed here is not suggestive of God as "becoming" as in say some forms of Processes theology. Secondly, as with all analogies between God and human's there are discontinuities within the continuity of characteristics to which we allude. Thus while the good-enough mother is largely unaware of the effects of her actions, but that the God encountered here, following with the literary interpretation, does not clue us in to we might say may be aware/not fully aware of the effects of his parenting.

${ }^{2}$ We are aware of the omniscience of God and the differences between mothers who sometimes attain results that are intentionally orchestrated. But note must also be made of the anthropomorphism in the descriptions of the God encountered in the Scriptures, one who sometimes tests creatures and comes to new "knowledge about them. See for example the sacrifice of Isaac in Gen 22:1-19.

${ }^{3} \mathrm{An}$ issue of note as we consider God as good-enough Mother is the intentional avoidance of inclusive or gender neutral language in this essay. The theological antecedents of using masculine language for God- Father for instance- have been well argued by Elizabeth Achtemeier who points to biblical and Christological reasons for maintaining masculine language for god without diminishing the fact that God is neither male nor female. In this essay, however, the thrust of the arguments beg for using a more familiar and endearing term which is more personal and which is diminished when avoiding the personal pronoun. Since my own reformed sensibilities align with the reasons Achtemeier articulates, the pronoun he is used throughout even while God is being conceived as mother. See also a recent article by Simon Chan, "Why we all God Father" http://www.christianitytoday.com/ct/2013/july-august/why-wecall-god-father.html?utm_source=ctweekly-

$\underline{\text { html\&utm_medium }=\text { Newsletter\&utm_term }=12557620 \& u t m \_c o n t e n t=200816637 \& u t m \_c a m p a i}$ gn=2013

${ }^{4}$ See examples such as the following: "I make peace and create evil. I the Lord do all these things." (Isaiah 45:7); Shall a trumpet be blown in the city, and the people not be afraid? Shall there be evil in a city, and the LORD hath not done it? (Amos 3:6); "Out of the mouth of 
the most High proceedeth not evil and good?"( Lamentations 3:38); "Thus saith the Lord; Behold, I frame evil against you, and devise a device against you."( Jeremiah 18:11)

\section{$\underline{\text { References }}$}

Achtemeier, Elizabeth. (1993) "Why God is not Mother" Christianity Today, August 16, 1993 issue.

Bidwell, D., \& Batiski, D. (2009). “Abundance in Finitude: An Exploratory Study of Children’s Accounts of Hope in Chronic Illness" in Journal of Pastoral Theology (Volume 19, No. 1).

Capps, D. (1990). Reframing: A New Method in Pastoral Care. Minneapolis: Fortress Press.

Chan, Simon (2013) Christianity Today, August 16, 1993 issue.

Dykstra, C. and Parks, S. (eds.) (1986). Faith Development and Fowler. Birmingham, AL: Religious Education Press.

Erikson, E. H. (1964). Insight and Responsibility New York, NY: W.W. Norton \& Company.

Farley, E. (2000). "Interpreting situations: an inquiry into the nature of practical theology" in Woodward James, and Pattison, Stephen (eds). The Blackwell Reader in Pastoral and Practical Theology. Malden, Mass: Blackwell Publishers.

Fowler, J. W. (1981). Stages of Faith: The Psychology of Human Development and the Quest for Meaning. San Francisco: Harper \& Row.

Greenberg, J. R., and Mitchell, S. A. (1983). Object Relations in Psychoanalytic Theory.

Cambridge, MA: Harvard University Press.

Habel, N. C. (1985). The Book of Job: A Commentary. Philadelphia: Westminster Press.

Jung, C. G. (1973). Answer to Job. Princeton: Princeton University Press.

Marcel, G. (1948). The Philosophy of Existence. London: The Harvill Press.

Pembroke, N. (2010). Pastoral Care in Worship: Liturgy and Psychology in Dialogue. London: T\&T Clark International.

Pruyser, P. (1963). "The Phenomenology and Dynamics of Hoping." Journal for the Scientific Study of Religion, 3, 86-96. 
(2005, 1990). "Hope and Despair" in Rodney, J. H., (ed.) Dictionary of Pastoral Care and Counseling, Nashville, TN: Abingdon. 532-534.

Swinton, J. (2007). Raging with Compassion: Pastoral Responses to the Problem of Evil. Grand Rapids, MI: Eerdmans.

Vogels, W. (1981). "The Spiritual Growth of Job: A Psychological Approach to the Book of Job." Biblical Theology Bulletin, 11, 77-80.

Winnicott, D. W. (1971). Playing and Reality. London: Tavistock/Routledge.

Winnicott, D. W. (1965). Maturational Processes and the Facilitating Environment: Studies in the Theory of the Emotional Development. London: Hogarth Press. 